\title{
ЕВРОСОЮЗ: К ИСТОРИИ ПЕСКО
}

Аннотация. В статье автор рассматривает историю возникновения дискуссии вокруг Постоянного структурированного сотрудничества и реализации этого проекта на современном этапе. Отмечено, что, несмотря на ряд позитивных шагов на пути построения ПЕСКО, которое демонстрирует новые тендениии в сфере безопасности и оборонь, пока ещё рано говорить об его окончательном успехе.

Ключевые слова: Постоянное структурированное сотрудничество, ПЕСКО, Европейский союз, Э. Макрон, Ж.-К. Юнкер.

В Европе не утихают дискуссии вокруг Постоянного структурированного сотрудничества (ПЕСКО $)^{1}$. Её вполне справедливо рассматривают как первый крупный практический шаг на пути к созданию в рамках ЕС Европейского оборонного союза, стратегической автономии Евросоюза и даже европейской армии.

ПЕСКО имеет свою историю. Впервые планировать ПЕСКО в Европейском союзе стали в самом начале нынешнего XXI в. (правда, тогда применялась другая аббревиатура - ПСК). Стартовал этот процесс в ходе подготовки к созданию Конституции ЕС (официально это был Договор о Конституции, но фактически речь шла только о ней). Для подготовки был созван на несколько лет специальный Европейский конвент, где одна из рабочих групп, которую возглавлял ветеран интеграционного процесса, будущий министр иностранных дел Франции экономист Мишель Барнье, занялась разработкой концепции и структур Общей политики безопасности и обороны. Одной из центральных тем группы стала идея Постоянного продвинутого сотрудничества, вокруг которой развернулась ожесточённая борьба.

На поверхности противники идеи выступали против создания привилегированных групп членов ЕС в сфере безопасности, за всеобщее равноправие и единогласие в делах обороны и безопасности. Подспудно же главный удар наносили силы, опасавшиеся, что реализация новой идеи нанесёт ущерб НАТО. С первой угрозой ПЕСКО справилось довольно легко через серию компромиссов, в одном из них было решено заменить слово «продвинутое» на «структурированное». Что касается противников из НАТО, то их сопротивление продолжается до сих пор и останется на будущее.

Как известно, план создания Конституции ЕС рухнул после референдума во Франции (и Нидерландах). Но её быстро (и лишь косметически) переделали в Лиссабонский Договор о Европейском союзе 2009 г. В нём была впервые конституирована Общая политика безопасности и обороны, и почётное место заняло ПЕСКО. Чтобы придать ему особую значимость, в договор включили специальное приложение, посвящённое ПЕСКО с детальной проработкой этой идеи создания групп членов Европейского союза, более других готовых решать проблемы обороны.

(C) Журкин Виталий Владимирович - академик РАН, главный научный сотрудник, почётный директор ИЕ РАН. Aдpec: 125009, Россия, Москва, ул. Моховая, д. 11, стр. 3. E-mail: zhurvit@rambler.ru.

DOI: http://dx.doi.org/10.15211/vestnikieran2201945

${ }^{1}$ Permanent Structured Cooperation (PESCO). 
А дальше наступила многолетняя пауза. Никто это ПЕСКО не создавал, да особенно и не вспоминал. Так шли год за годом. Охранители НАТО чувствовали себя спокойно.

К ПЕСКО ЕС вернулся только почти десятилетие спустя.

Новый этап в развитии Общей политики безопасности и обороны Евросоюза начался несколько лет назад. Он был порождён рядом факторов - политикой президента США Трампа, брекзитом, ещё ранее - возросшим стремлением ЕС к самоутверждению на международной арене. Его чётко обозначили председатель Европейской Комиссии Жан-Клод Юнкер, президент Франции Эммануэль Макрон, канцлер Германии Ангела Меркель, другие европейские лидеры, призвавшие к стратегической автономии ЕС и созданию европейской армии.

В новых условиях практически неизбежным стало обращение к полузабытому ПЕСКО. Его возвращение прошло несколько этапов.

22 ноября 2016 г. Европейский парламент принял решение об учреждении в перспективе в рамках ЕС Европейского оборонного союза, что создало определённую концептуальную базу для последующих усилий. Первым из них стало обращение к ПЕСКО. И после серии подготовительных встреч и совещаний 11 декабря 2017 г. Совет Европейского союза принял решение о его реализации.

На первом этапе в ПЕСКО включили 17 совместных проектов - организационных мер, программ кибербезопасности, военно-морской сферы, создания бронетехники и др. Помня о выступлениях против «привилегированности», в ПЕСКО включили 25 стран-членов. За пределами остались Дания, традиционно не участвующая в военных усилиях ЕС, и маленькая Мальта.

Решение о начале практической реализации ПЕСКО вызвало волну поддержки в Европейском союзе. Верховный представитель ЕС по иностранным делам и политике безопасности Федерика Могерини назвала решение о ПЕСКО историческим. Несколько ранее, чтобы обеспечить финансирование проектов ПЕСКО, был создан Европейский оборонный фонд. В нём предусмотрено ежегодно выделять на эти цели 5,5 млрд евро.

Более или менее определёнными стали временные рамки всего этого процесса. Ж.-К. Юнкер в своём ежегодном послании «Состояние Союза. 2017» определил срок формирования Европейского оборонного союза к 2025 г. Дональд Трамп обрушился на планы европейской армии с резкой критикой. В натовских кругах выразили надежду, что все эти есовские новшества рано или поздно будут подмяты альянсом.

История ПЕСКО призывает к известной осторожности в прогнозах. Вместе с тем факт остается фактом - в Евросоюзе нарождаются новые тенденции в сфере обороны и безопасности. И ПЕСКО, вступившее, наконец, в стадию практической реализации - одно из важнейших этих новшеств.

\section{European Union: History of PESCO}

Author. Vitaly Zhurkin. Academic, Honorary Director, Institute of Europe, Russian Academy of Sciences. Address: 11-3, Mokhovaya str., Moscow, Russia, 125009. E-mail: zhurvit@ rambler.ru.

Abstract. In the paper the author studies the history of discussion regarding the Permanent Structured Cooperation and the implementation of this project at the present stage. It is noted that despite a number of positive steps towards the construction of PESCO it is still early to talk about its ultimate success. However, PESCO demonstrates new trends in the field of security and defense.

Key words: Permanent structured cooperation, PESCO, European Union, E. Macron, J.-C. Junker.

DOI: http://dx.doi.org/10.15211/vestnikieran2201945 